\title{
Legal Remedies of Legalization (Money Laundering) Proceeded by Crime
}

\author{
Oksana Trocenko*, Irina Soshnikova
}

\author{
Ural State Economic University, Ekaterinburg, Russia \\ ${ }^{*}$ Corresponding author. Email: trocenko.o@mail.ru
}

\begin{abstract}
The problem of money laundering has become one of the acute problems in recent years, both at the domestic and international levels. The article examines the generating factors, analyzes the national and international experience in combating money laundering, the authors propose a set of measures to counter money laundering
\end{abstract}

Keywords: income, money laundering, anti-legalization, crime

\section{INTRODUCTION}

The relevance of this topic is caused by an increase in the flow of funds received as a result of committing crimes into the legal economic turnover, and, consequently, it poses a danger to the state economy. In addition, the strengthening of the processes of global globalization in all sectors of society, and especially in the sphere of the world economy, causes the spread of the problem of legalization throughout the world, consequently, the direct link between legalization and the financing of terrorism poses a threat to the entire world community.

\section{MATERIALS AND METHODS}

To date, the problem of countering the legalization (laundering) of criminally acquired income is not new for Russia. The legislative framework for countering the legalization of criminal proceeds began to take shape with the adoption of the Criminal Code of the Russian Federation in 1996, where it is understood as the legalization (laundering) of funds or other property acquired by other persons by criminal means, the commission of financial transactions and other transactions with funds or other property knowingly acquired by other persons by criminal means, in order to give a legitimate form to the possession, use and disposal of the specified funds or other property .Definition of legalization (laundering) of funds or other property acquired by a person as a result of committing a crime, given by art. 174.1 of the Criminal Code of the Russian Federation, differs only by the subject of the crime from the definition specified in Article 174 of the Criminal Code of the Russian Federation [3].

According to V. M. Aliyev, legalization is caused by a complex complex of various reasons and conditions. At the same time, he divides the factors that determine legalization and contribute to it into three main groups:

1. Political and economic factors (affect the legalization (laundering) of income indirectly);

2. Socio-legal factors (affect the sphere in which income is directly legalized);

3. Moral and psychological factors (determine the corresponding criminal behavior of a person) $[5,238 \mathrm{p}]$. As economic factors of legalization (laundering) of criminal proceeds, the economic theory of crime is called, the essence of which is expressed in the fact that the appearance on the market of a large number of specialists in the field of banking, law, financial management and tax law leads to an overflow of the market of these professions, high competition among these persons, and as a result, a decrease in the level of wages for persons of these specialties. As a result, these persons come to the conclusion that the use of their knowledge is possible in illegal activities, since there they can get a more favorable payment for their work, despite the opposite of such acts.

Another economic factor that generates legalization is the possibility of obtaining a significant profit with a low probability of detecting a crime and, accordingly, with a low probability of being brought to justice.

The demand for services for the legalization (laundering) of criminal proceeds is also a determinant 
factor of the crimes under consideration. Based on the economic law of supply and demand, we can say that the demand for services for laundering criminal proceeds will entail an offer from entities that are ready to carry out legalization for a certain fee.

As legal factors of legalization, the need to hide not only the criminal nature of the proceeds, but also the crime itself, as a result of which they were obtained, is highlighted. As well as the imperfection of legal regulation in this area, since, to date, there are gaps in the legislation that allow circumventing the law.

The moral and psychological factors include the low level of legal awareness of the population, the legal nihilism generated by it, characterized by persistent neglect and a negative attitude to the law. In the legal consciousness of citizens, there is an attitude to achieve socially significant goals by means in which there is a minimum application of normative acts, as well as the use of non-legal means. The complexity of the formulas of legislation often leads to a wrong perception of their actions by the subjects of legal relations, so, when committing an act prohibited by criminal law, a person does not know that he is committing a crime, and perceives it as a legitimate action.

The affiliation of the legalization (laundering) of criminal proceeds to economic crimes allows us to identify determinants of a general and special nature. The conditions that affect the commission of crimes in the economic sphere are general determinants, and those factors that act directly in the field of legalization are special determinants. This classification of determinants makes it possible to distinguish the criminological measures of a general and special nature that affect the legalization of criminal proceeds.In addition to the previously mentioned determinants of the legalization (laundering) of criminal proceeds, as general determining factors, we can distinguish:

1. The destruction of the system of social guidelines, which previously fixed the prevalence of moral values over material values in the minds of people;

2. Active lobbying in the political sphere of the interests of unscrupulous entrepreneurs, as well as leaders of criminal groups [7, 62-75 p.] ;

3. Planting in the minds of citizens with the help of mass culture of images that represent material values as the highest value, as an obligatory element of success;

4. Neglect of the historical experience in the field of combating economic crimes, developed in their own country, as well as in other countries.

Special determining factors of legalization (laundering) of criminal proceeds are:

1. The entry of the legalization of criminal proceeds to the international level, as well as weak international cooperation in the field of countering the laundering of illegal income, despite significant international legal regulation of this area;

2. Insufficient interdepartmental interaction within the country in the field of countering the legalization (laundering) of criminal proceeds, as well as the weak professional potential of law enforcement officials due to the low level of professional training.

As another factor that can provoke the legalization of criminal proceeds, we can highlight the increase in the number of offshore zones around the world. Offshore zones have significant advantages, which attract the subjects of money laundering. Such advantages are:

1. A high level of loyalty of the states on the territory of which offshore zones are located;

2. Compliance with the secrecy of deposits and other banking and commercial secrets, restriction of access of law enforcement agencies to banking information;

3. The possibility of preserving the anonymity of account holders and their counter-agents for transactions performed;

4. No currency restrictions, free export of profits, as well as other advantages.

As a result of the provision of such benefits, offshore zones, by their very nature, have become a transshipment point for the subsequent entry of" laundered " capital into the economy of Russia and other countries. Developed countries currently do not support the use of offshore zones by their residents, as they see this as a failure to receive funds to the budget, as well as uncontrolled export of funds from the country, while the nature of the origin of this money is often criminal.

\section{RESULTS AND DISCUSSION}

In addition to the considered reasons and conditions for the legalization of criminal proceeds, it is also advisable to distinguish a group of technical reasons and conditions that determine legalization. These include:

1. Imperfection of the applied cash register equipment;

2. The slow introduction of the latest computer programs that allow us to assist in identifying acts of legalization, as well as allow us to analyze the financial activities of citizens and legal entities from the point of view of committing suspicious transactions [10, 27 p.];

3. Development of technologies in the field of performing transactions with monetary funds in electronic form on the Internet. At the same time, despite the existing prohibitions on operations on the 
Internet, there are ways to circumvent these restrictions using technologies for creating encrypted channels.

The determinants of the legalization of criminal proceeds considered in this paragraph should be analyzed by the legislator and the law enforcement officer together, since the elimination of only one factor will not entail a change in the existing situation in the AML/CFT sphere, since these factors are closely interrelated with each other, while the destruction of several factors considered will cause a decrease in criminal activity in the area under consideration.

Among the factors that must be taken into account when developing measures to prevent the legalization (laundering) of proceeds from crime, the most important ones can be identified, which include: the deterioration of the financial situation of citizens and legal entities, the low level of legal culture of the population, as well as the imperfection of legislation in this area. Consequently, getting rid of at least these determinants will contribute to a reduction in the turnover of the legalization of criminal proceeds.

To date, in order to protect the rights and legitimate interests of citizens, society and the state, in the Russian Federation, in accordance with the requirements of the Group for the Development of Financial Measures to Combat Money Laundering (FATF), there is a system for countering the legalization (laundering) of illegal income and the financing of terrorism. Relations concerning the prevention, suppression and detection of acts of legalization are the relationships between entities that include, on the one hand, citizens of the Russian Federation, foreign citizens, stateless persons, as well as economic entities that carry out transactions and transactions with money and other property, and on the other hand, these are state bodies and international organizations whose activities are aimed at combating AML/CFT.

Within the framework of the national AML/CFT system, an Interdepartmental Working Group (IWG) was established in 2012 to coordinate the actions of participants to counteract the commission of illegal transactions and financial transactions, which performs a coordinating function to ensure the cooperation of state bodies and the Bank of Russia to prevent the withdrawal of funds into the shadow economy and outside the territory of Russia.

The Central Bank of the Russian Federation has become one of the most important anti-legalization bodies in this area, and therefore it has received the functions of a financial megareulator. Such functions consist of the following functions: supervision, licensing, inspection of credit and insurance organizations, professional participants in the securities market, management companies, consumer credit cooperatives, microfinance organizations.
Also, as measures aimed at countering legalization, we can name internal control in credit institutions, the creation of a single information database, the introduction of liability for violations of legislation in the field of AML/FT $[9,345-350$ p.].

It is advisable to designate as a direction of countering the legalization of criminal proceeds the use of measures aimed at preventing illegal capital from entering the financial market by eliminating organizations that carry out suspicious financial transactions and transactions.

Another important area is banking control, which allows banks to refuse to conclude bank deposit (account) agreements with customers if there are suspicions that the contracts under consideration are being used for the legalization (laundering) of criminal proceeds, as well as the possibility of terminating such agreements. In addition, the Bank of Russia has been granted the authority to draw up lists of clients that banks need to pay attention to. Such clients, in addition to persons making suspicious transactions, include persons to whom there is a debt of non-residents under foreign trade contracts $[6,74-80$ p.].

As technical measures of a preventive nature, there are:

1. Implementation of document management in organizations both in paper and electronic form, and in addition, compliance with the rules of storage and circulation of documents containing information about the activities of the organization, about its customers and transactions;

2. The use of add-ons to the software products of banks, which may contain data on the completed business transaction in such a form that, if necessary, it was possible to restore the operation in detail, with the specifics of the economic activity of the organization $[8]$.

Despite the fact that technical measures do not form the basis for countering the legalization of criminal proceeds, compliance with such measures creates certain difficulties for the commission of laundering of criminal proceeds.

Based on national and international experience, we can say that the complex of the system for countering the laundering of proceeds from crime should contain such components as:

1. Implementation of state regulation aimed at countering the laundering of illegal income, which should include both the regulation of economic activity, especially in the financial sphere, and the regulation of banking activity in terms of de-tender and credit policy, while state regulation should proceed from a previously adopted comprehensive system of measures; 
2. Management of threats and risks of criminalization of the economy in various spheres $[8,2$ 12 p.];

3. Withdrawal of the capital of residents of the Russian Federation from offshore zones, by providing the maximum possible guarantees and concessions for this category of subjects;

4. Conducting expert examinations of economic projects for the presence of elements of corruption and money laundering in them;

5. Improvement of the legal framework for countering money laundering and other property;

6. Education of anti-criminal morality in society.

These measures originate from various spheres of regulation and constitute a single complex of countering legalization, therefore, achieving an effective result of their application is possible only with their combined use, since in this case, the counteraction will be carried out simultaneously in a large social and legal space.

\section{CONCLUSIONS}

Having analyzed the system of measures to counteract the legalization of funds and other property, we can draw the following conclusions:

1. The state is the only entity that, by means of international cooperation and delegating its powers to state bodies capable of providing significant opposition to the legalization of illegal income;

2. To date, the effectiveness of the anti-legalization system is achieved through the use, mainly, of an imperative method of combating it, since most of the measures applied in this area are characterized by a sign of power and subordination;

3. The measures applied to date in this area are mostly aimed at increasing the level of transparency of financial transactions and transactions, strengthening control over their legality;

4. The achievement of effective results in the field of countering legalization directly depends on the international cooperation of States in this field, as well as on the convergence of legal norms in preventing the existence of centers for the legalization of criminal proceeds.

To date, the legalization (laundering) of criminal proceeds is an economic crime that has dangerous consequences for the financial well-being of the state in the form of a decrease in the economic stability of the state caused by the withdrawal of funds from legal economic activities, as well as an increase in the share of the shadow economy.
The interconnectedness of the financial markets of states leads to the fact that a significant amount of criminal funds entering them has a negative impact on the state of financial stability of the world economy. In addition, the frequent connection of the legalization of criminal proceeds with terrorist financing activities entails a threat to the world law and order. In this regard, the crime of laundering the proceeds of crime is an international problem and is subject to joint resolution by the States.

\section{REFERENCES}

[1] Against Transnational Organized Crime: United Nations Convention of November 15, 2000 (as amended from 15.11.2000) meeting of the legislation of the Russian Federation, 40 (2004) pp. 3882 .

[2] Convention on laundering, search, seizure and confiscation of the proceeds from criminal activity: the Council of Europe Convention of 8 November 1990. Meeting of the legislation of the Russian Federation, 3 (2003) pp. 203.

[3] Criminal code of the Russian Federation of 13.06.1996 No. 63-FZ (ed. by G. 07.04.2020). meeting of the legislation of the Russian Federation, 25 (1996) pp. 2954.

[4] On countering the legalization (laundering) of proceeds from crime and the financing of terrorism: Federal law of August 7, 2001 No. 115FZ (as amended on April 7, 2020), meeting of the legislation of the Russian Federation, 33 (2001) pp. 3418 .

[5] V. M. Aliyev, Legalization (laundering) of incomes received by illegal means: criminally-legal and criminological research. M.: ES, 2001.

[6] R. V. Zhubrin, Prevention of legalization of criminal proceeds. Legal science and law enforcement practice, 1 (2016).

[7] O. V. Zimin, Factors of legalization (laundering) of funds or other property acquired by criminal means // Bulletin of the Academy of Economic Security of the Ministry of Internal Affairs of Russia, 9 (2009).

[8] V. V. Melnikov, M. V. Vakareva, Methods of legalization of income obtained by criminal means, and measures of state counteraction, Science and Education today, 12 (2017).

[9] G. I. Khokhlova, V. M. Pakholchenko, Countering the legalization of illegally obtained income as a factor in increasing the country's investment potential. Bulletin of the Irkutsk State Technical University, 4 (2015). 
[10] T. M. Chapurko Actual problems of criminal law and politics. Methodological guidelines for the study of the discipline for master's students studying in the field of training "Jurisprudence", the program " Criminal law. Criminology". Saratov: Ai Pi Er Media, 2017.

[11] N. M. Shpak, Measures to counteract the legalization (laundering) of proceeds obtained by criminal means. Polythematic network electronic Scientific Journal of the Kuban State Agrarian University, 5 (2015). 